\title{
Introductions and developments of oysters in the North Sea area: a review
}

\author{
A. C. Drinkwaard \\ Senior Mariculture Services, Isle of Texel, P.O. Box 135, 1790 AC Den Burg, \\ The Netherlands
}

\begin{abstract}
ABSTRAC:T: To replenish the exploited native stocks of Ostrea edulis, imports from almost all European coasts have arrived in the North Sea, particularly in the Dutch Oosterschelde estuary. The American oyster Crassostrea virginica and the Portuguese oyster C. angulata have also been imported in to the North Sea several times. However, only the introductions of various genetic strains of the Pacific oyster C. gigas have been of lasting success. Spat from British Columbia (Canada) was first imported to the Oosterschelde in 1964. First spatfalls in this area took place in the warm summers of 1975 and 1976 . Further larval outbursts occurred in 1982 and 1989, and good settlements took place on culture plots as well as along the dikes of the Oosterschelde. Since 1977 no more cupped oysters have been imported from overseas. The population maintained itself and was able to spread in a northern direction along the Dutch North Sea coast. In Britain, hatchery-produced C. gigas were transferred to several sites, in the 1970 s including the British North Sea coast. Here, occurrence in the wild seems to be rather limited up to now. Into the German Wadden Sea, C. gigas larvae and spat from a Scottish hatchery have been introduced since 1971, as were medium-sized oysters from a variety of European sources in the 1980s. Strong spatfalls on intertidal mussel beds in the northern German Wadden Sea occured in 1991 and 1994. For the introductions of C. gigas along the west European coasts, precautionary measures to minimize unintentional transfers of associated organisms, as recommended by the ICES Code of Practice in 1994, came too late.
\end{abstract}

\section{INTRODUCTION}

The Pacific oyster Crassostrea gigas (Thunberg, 1793) is native to Japan. Based on morphological and physiological characteristics, Imai \& Sakai (1961) identified four local races which they called Hiroshima, Hokkaido, Kumamoto and Miyagi strains. In this context it is important to know that Imai \& Sakai (1961) were easily able to produce hybrids of C. gigas and C. angulata, the Portuguese oyster (see also Menzel, 1974). Boudry et al. (1998) showed that the latter seems to originate from Taiwan and can be genetically distinguished from C. gigas. The various strains, crossings and environmental differences make the 'cupped oysters' or 'creuses' highly variable in shape. More than once in the past, attempts have been made to revive exploited stocks of the European flat oyster Ostrea edulis with imported American Crassostrea virginica and Portuguese C. angulata at several sites on the North Sea coasts (Neudecker, 1985; Eno et al., 1997). These attempts largely failed. Early in the 1970s, the Dutch oyster farmers were growing cupped oysters of the genus Crassostrea to a limited extent. These must have been of Portuguese, Japanese or mixed origin. In 1980 it was reported that virtually no C. angulata oysters were left in Dutch waters.

( Biologische Anstalt Helgoland, Hamburg 

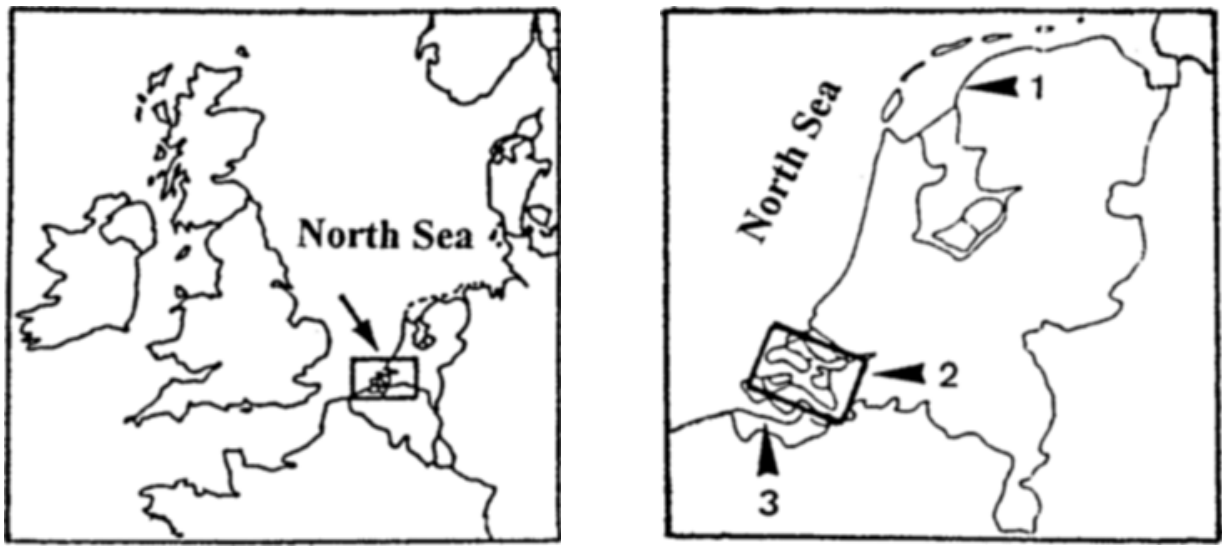

Fig. 1. Position of the south-west of The Netherlands to the North Sea. 1 Wadden Sea; 2 Oosterschelde and Lake Grevelingen; 3 Westerschelde

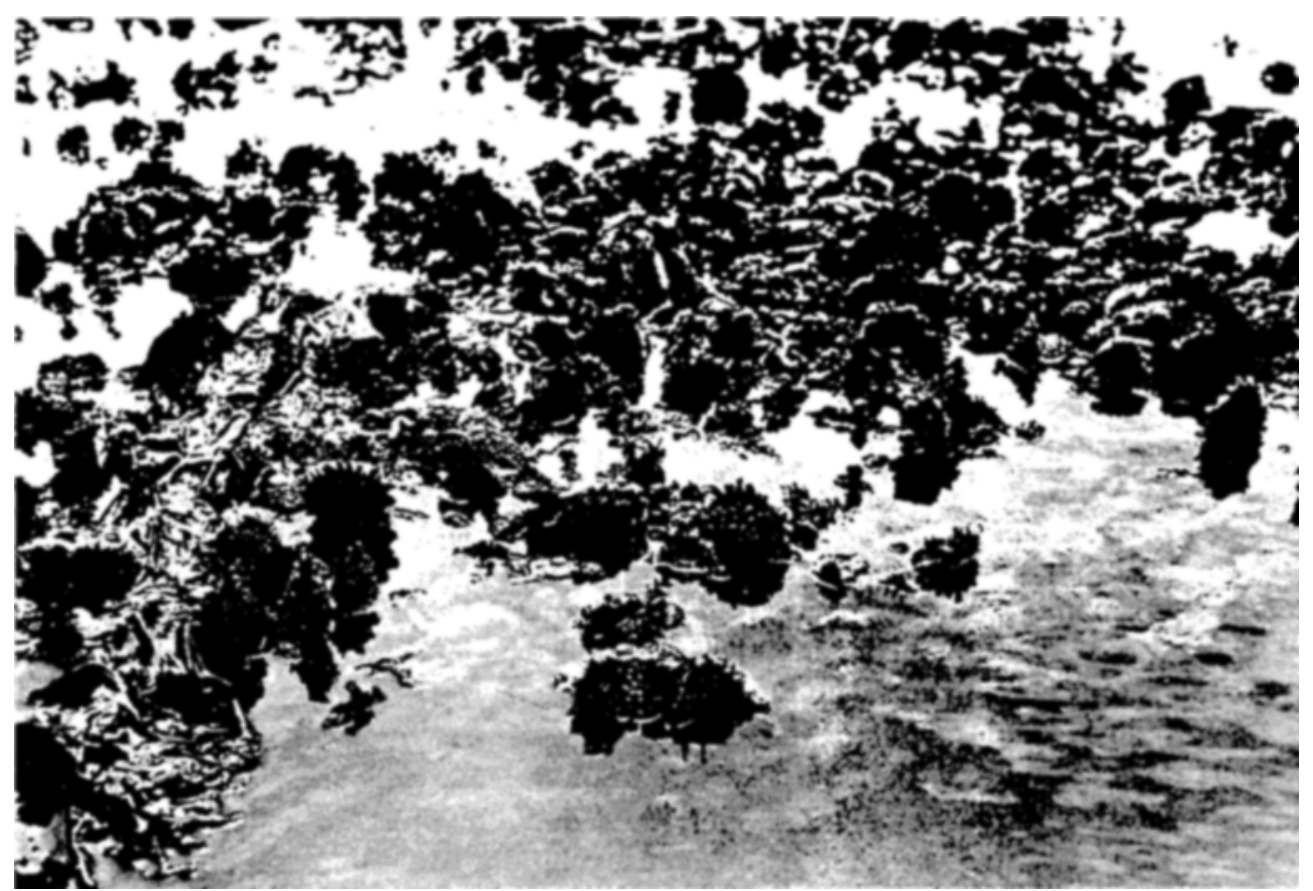

Fig. 2. Natural broodstock of Crassostrea gigas on the Yerseke bank, Oosterschelde estuary, 9 August 1982

At the beginning of this century trial plantings of C. gigas were started in the northwestern part of America. Here, spawning populations have become established in several areas since the 1930s (Steele, 1964). More recently, other cases of C. gigas intro- 
ductions have shed some light on the potential of this oyster to become established (Walne \& Helm, 1979; Beattie, 1983; Grizel, 1988; Quayle, 1988; Chew, 1990; Ayres, 1991; Dinamani, 1991). The history of oyster introductions into the Dutch coastal waters has not been described before. For locations see Fig. 1. To bring this into perspective, introductions of $C$. gigas to other North Sea coasts are also considered in this review.

In the case of the Dutch C. gigas importations, it was not predicted that offspring were to be expected. In 1966 the oyster farmers were informed that the introduction of the Pacific oyster as seed stock was acceptable since these oysters could not reproduce at the latitude of the Dutch coastal waters. However, in 1976 spat settlement on jetties and rocky dike foots was obvious enough. In an official report it was concluded that "Perhaps measures are necessary to nip this spatfall in the bud!" Political pressure stopped the importation of C. gigas in the following year. At that time 20-30 million socalled weed oysters was the estimate. The hand-picking of oysters along the dikes was decontrolled to reduce the cupped oysters. Also, in 1981 the littoral zone outside the culture plots was opened up to the public fishery. However, the thinking changed in 1982 with a new natural larval outburst with up to 50 cupped oyster larvae per $100 \mathrm{l}$ Oosterschelde water as against 50 . edulis larvae. From that time on the new 'creuses' were accepted as belonging to the fauna of The Netherlands (Fig. 2) and the commercializing of the Dutch cupped oyster stock could really start.

\section{THE DUTCH STRUGGLE IN PRODUCING OYSTERS}

\section{The flat oyster Ostrea edulis}

Before the severe winter of 1962/1963 in the Zeeland streams (Oosterschelde estuary) usually three year classes of $O$. edulis participated in reproduction. The estimated stock size was 120 million oysters. After that winter the number was reduced to 4 million to which soon 6 million oysters from Brittany (France) were added. The market production in the years before the winter catastrophe was about 30 million oysters per year. Looking around in Europe, the Norwegian pond culture of $O$. edulis seed was one of the possibilities to enlarge the broodstock. More than 20 million spat and seed oysters were delivered in 1963 and 1964. In spring 1967 some 15 million oysters were imported from Brittany, some from Ireland and some from natural beds in the Adriatic Sea. During 1967 the climatological circumstances were favourable for a good spatfall. It was estimated that the spat collection on $3000 \mathrm{~m}^{3}$ mussel shells amounted to 50 million, the first good set since the disastrous winter.

Struggling from year to year, considerable quantities of flat oysters were still being imported in the 1970s. However, Aber disease among flat oysters in Brittany, caused by the protozoan Marteilia refringens, made it necessary to instruct the importers to limit their purchases to unaffected areas with the help of the French authorities. In 1975 only marketable oysters for direct delivery were imported. In 1977 the O. edulis farmers imported oysters from England, Ireland, Italy and Greece. Thus, nearly all European strains of the flat oyster came together in the Oosterschelde and there was a spatfall of a completely mixed broodstock. The high mortality during the following winter among these spats had to be ascribed to the low winter hardiness as compared with the spat of 
the original Zeeland broodstock in the marine Lake Grevelingen nearby. The interbreeding with Atlantic and southern strains of the flat oysters had a negative effect on the offspring.

The same happened with Dutch Wadden Sea oysters, after the former Texel oyster fishers and merchants imported large quantities of French oysters. The O. edulis Wadden Sea strain reproduced at $15^{\circ} \mathrm{C}$ and was sufficiently winter hardy for this area. However, since 1962 they have completely gone. In the marine Lake Grevelingen, since 1971 a tide-free locked sea-arm, a spatfall of O. edulis was observed rather unexpectedly in 1975. The numbers of spat were high in relation to the small number of adult oysters staying behind, thanks probably to the absence of seawater exchange and lack of predators. The oyster stock in Lake Grevelingen had been out of commercial production since 1964 and was not mixed with foreign imports.

\section{The cupped oysters Crassostrea angulata and C. gigas}

In 1964 a Dutch oyster farmer imported spat of the Pacific oyster from British Columbia. This spat was settled on empty shells and placed on trays in the water supply channel of a large lobster storage park at Yerseke (Oosterschelde estuary). In this channel a continuous flow of seawater was guaranteed. On arrival in May the spat was about $1 \mathrm{~cm}$ in diameter. In September the spat of the Kumamoto strain had grown to a length of $5 \mathrm{~cm}$ and the spat of the Miyagi strain up to $10 \mathrm{~cm}$. After the winter of $1964 / 1965$, the oysters were separated from the collector shells and brought to an oyster culture plot on the Yerseke Bank, belonging to the Molluscan Shellfish Department of the Netherlands Institute for Fishery Investigations (personal observations). On this plot the growth was followed till the end of 1965, when the oysters were raked from the bottom. The growth in length of the Miyagi strain oysters had been too fast for a marketable shape, while the growth of the Kumamoto strain was acceptable but could have been better. In 1966 experiments were also carried out with the Japanese strain of the Hiroshima area (Korringa, 1976), but nearly nothing is reported about the introduced quantities. In covert terms the incoming consignments of Japanese spat were 'fair' and showed a remarkable growth.

The French investments in Japanese oysters did not escape the notice of the Dutch, but they did not expect a spatfall in their own waters. However, in 1975 this happened during a very warm summer when $10000 \mathrm{~m}^{3}$ mussel shells as collectors for $O$. edulis spat were laid on about 500 ha of the Oosterschelde bottom. The spat also settled onto some shallow intertidal mussel plots. The real breakthrough came with the spawning again in 1976. The cause of this new situation was the fact that the temperature of the seawater in the Oosterschelde rose above $20^{\circ} \mathrm{C}$ on 25 June and remained above that level till the end of July. Also, during the second half of August the temperature was again above $20^{\circ} \mathrm{C}$. That meant 50 days in total. After arrival of the already ordered spat from Japan and the United States., these importations came to an end in 1977. For 1979 it is reported that marketable $C$. gigas oysters were imported 'largely' from France and Belgium. In Belgium, depot basins were established at Ostend; nearby a pilot-scale installation for nursery culturing of bivalve molluscs, e.g. C. gigas, was in operation during 1979-1982. In 1981 all importations from France to The Netherlands were stopped 


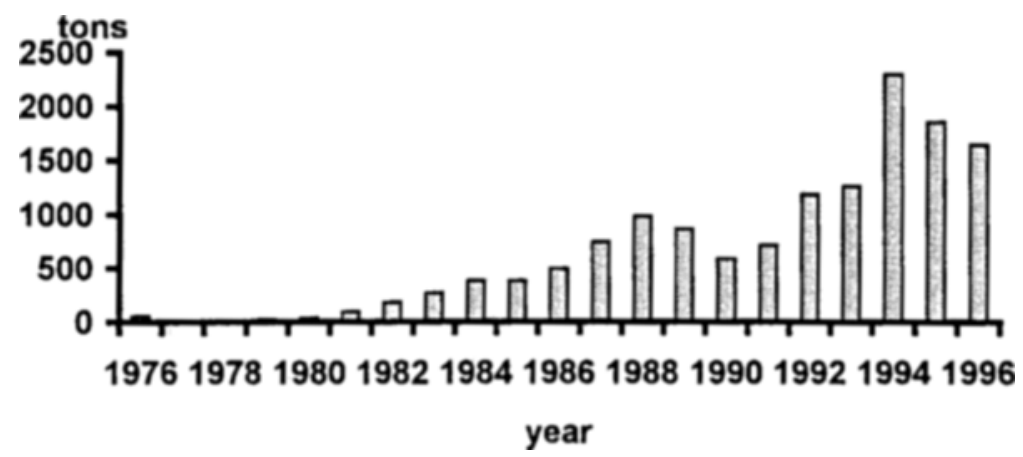

Fig. 3. Harvest of Crassostrea gigas in the Netherlands in tons per year. One ton corresponds roughly to 9000 oysters

and all planting of such oysters in the Oosterschelde was prohibited, because a new disease, caused by the protozoan Bonamia ostreae, had been introduced. The policy of checking and granting the importations from abroad had failed. The definitive introduction of the cupped oysters became a matter of fact by a new natural larval outburst in July 1982. With limecoated plates the broad outlines of the spat settlement of this progressive and dynamic population could be followed. Also, the fair footing of the 1-yedr-old spat along the dikes of the western part of the Oosterschelde became a normal sight. As had been done 25 years ago for the flat oysters, the larvae of the cupped oysters were monitored, ranging from 5 to 15 larvae per $100 \mathrm{l}$ in 1984 to 75 larvae per $100 \mathrm{l}$ in 1989, with an abundant spatfall afterwards. An increase by a few degrees above the 'normal' seawater temperature in summer leads to new recruitment to the wild and cultivated populations, as in 1986. Also, the duration of the reproductive season is important. During the 1990s the harvest per season, including the wild fishery, may surpass 2000 tons (Fig. 3). About 20 growers, more or less in the margin of other activities, are occupied with this fairly new farming operation.

The marine Lake Grevelingen could not be kept free from the new cupped oysters. A spatfall in 1987 had to be accepted. In the Dutch Wadden sea, only medium-sized and somewhat larger cupped oysters were reported by Dutch mussel farmers who were relaying imported mussels from the Danish and northern German Wadden Sea. Transport of mussels from the Oosterschelde estuary to the Dutch Wadden Sea occurred during a short period too. Otherwise, larvae may escape via the Oosterschelde storm-surge barrier and drift in mostly a northern direction with the residual current at a speed of 8-10 $\mathrm{km} \operatorname{day}^{-1}\left(0.1 \mathrm{~m} \mathrm{~s}^{-1}\right)$. The distance to the entrances of the Dutch Wadden Sea is not more than $200 \mathrm{~km}$.

Settlement of C. gigas in littoral locations of the Westerschelde (sporadic during the 1980 s, but increasing during the beginning of the 1990s) may either be due to spreading from the Oosterschelde, or to the experimental nursery rearing along the Sluice Dock of Ostend. The distance from Ostend to the mouth of the Westerschelde is only $40 \mathrm{~km}$. 


\section{CUPPED OYSTERS IN GREAT BRITAIN}

After a Portuguese oyster trade of 10-20 million oysters a year during the 1950s and early 1960s, a new start was made with the Japanese oyster C. gigas. In 1965 the MAFF Shellfish Culture Unit at Conway (Wales) received a small consignment of $C$. gigas oysters from British Columbia (Canada). In a controlled breeding programme the oysters were successfully induced to spawn in 1965 and 1966 (Walne \& Spencer, 1971). At the beginning of the 1970s batches of hatchery-produced Japanese oyster seed were grown in stacks of trays, held on rafts, at five different sites: Menai Strait (Wales), Helford (Cornwall), Poole Harbour (south coast of England), Paglesham and Walton (North Sea coast).

Since the end of the 1970 s the annual production of C. gigas seed by the operating hatcheries and nurseries in Great Britain has increased continuously. In 1997 the annual production was in the range of 200 million spat oysters per year (J. C. Bayes, personal communication). In 1979 the MAFF Conway hatchery imported small numbers of C. gigas from Oregon (USA) to improve the viability of the broodstock (Utting \& Spencer, 1992). This became 'common sense' for the other hatcheries too. To maintain viable hatchery broodstocks, different strains of the Pacific oyster have been used from various locations. In 1977 the UK already had a marketable C. gigas stock of 100 tons. In 1983 there were 175 tons of marketable oysters available, while the Shellfish Association of Great Britain estimated a 1997 harvest of 1000 tons from more than 1000 sites used for production.

The effect of the UK Wildlife and Countryside Act of 1981 on the Pacific oyster industry is not clear. The Nature Conservancy Council must be consulted before licences are granted for releasing animals of a species that is not ordinarily resident in the wild state or not a regular visitor. It has been stated that the British climate is unsuitable to the natural reproduction of $C$. gigas, but during recent years some sporadic spatfalls in the wild have been observed at some places along the British coast, e.g. Emsworth Harbour. However, till now the production is in no way sustained by natural populations as it is in France and The Netherlands (E. Edwards, personal communication).

\section{CUPPED OYSTERS IN GERMANY}

Several attempts to revive the former $O$. edulis stock in the German Wadden Sea have failed. Besides $O$. edulis, also $C$. virginica and $C$. angulata have been imported. Early attempts before the war with flat and cupped oysters of Dutch and French origin showed good stock growth, but they did not resist the hard winter conditions. In June 196125 metric tons of C. angulata were relaid near the Isle of Föhr, of which only $10 \%$ survived. In 1971 C. gigas was introduced into the German waters for the first time. These 0-group oysters were imported from a Scottish hatchery for a raft culture experiment in the Wadden Sea off the island of Sylt. In 1972, again spat of the same origin was imported. Growth was successful in this North Sea area. At the end of the 1970s both outdoor experiments on the growth and fattening to marketable oysters and indoor experiments devoted to the rearing of spat from larvae were continued.

In 1985 private commercial enterprises started up with production on the basis of the acquired knowledge. In 1987 farming activities were in operation near the islands 
of Norderney and Sylt. The overall commercial production of Pacific oysters was then at the level of about 25 tons a year. In 1988 the total German harvestable production doubled to 55 tons, about 600000 oysters a year. However, the doubling of the sales was based especially on imported medium-size oysters. Their origin was quite diverse, from England, Scotland, Wales and Ireland. The sale expectations for the season 1989-1990 were 1 million oysters (Dittmeyer, 1989).

The Sylt company was looking for Pacific oyster strains with a compact shape. They did not want the long 'bananas' of French origin. The supplies from the Dutch Zeeland area, England and Ireland were good for the market. The method of culturing these oysters in mesh bags on trestles in an intertidal off-bottom position may well increase the possibility of spawning and releasing of the gametes. Not only does this make the oysters more saleable, but also recruitment by settling of larvae in the wild can be expected. Spatfall near the island of Sylt was observed at the beginning of the $1990 \mathrm{~s}$ (Reise, 1998). The present natural intertidal mussel beds formed a good substrate for the strong spatfalls in 1991 and 1994. It was estimated that the wild Pacific oyster population between the islands of Sylt and Rømø was in the region of 1 million oysters in 1995 . with a survival in 1996 of $60-70 \%$ after a severe winter. The consequences of this population whose progeny crossed the Danish border are not yet surveyable.

\section{PROPOSITIONS}

For ecological and maricultural understanding of the patterns and processes that lead to successful or unsuccessful introduction of non-indigenous organisms we need more than our present-day knowledge. For the introduction of C. gigas along the west European coasts the framed decision-models came too late to be of use. Several questions have now been formulated in the ICES 1994 Code of Practice on the Introductions and Transfers of Marine Organisms. In practice, recommended procedures prior to reaching a decision regarding introductions are not applied to introductions or transfers which are part of current commercial aquaculture activities. It can be expected that by the yearly importation of Pacific oysters from different sites and origins, the Sylt farming location may have a function in the development of the gene pool of the nearby natural populations. It is not possible to say in which direction this influence will go - a reduction in the genetic diversity or an increase in the viability? The genetic variability in the introduced stocks and their offspring may be high. These genetic aspects need further study.

\section{LITERATURE CITED}

Ayres, P., 1991. Introduced Pacific oysters in Australia. In: The ecology of Crassostrea gigas in Australia, New Zealand, France and Washington State. Ed by J. Sutherland \& R. Osman. Maryland Sea Grant College, 3-7.

Beattie, J., 1983. An overview of oyster culture on the Pacific coast. - Proc. North. Am. Oyster Workshop Spec. Publ. 1, 11-15.

Boudry, P., Heurtebise, S., Collet, B., Cornette, F. \& Gérard, A., 1998. Differentiation between populations of the Portuguese oyster Crassostrea angulata (Lamark) and the Pacific oyster Crassostrea gigas (Thunberg), revealed by mtDNA RFLP analysis. - J. Exp. Mar. Biol. Ecol. 226, 279-291. 
Chew, K. K., 1990. Global bivalve shellfish introductions. World Aquacult, 21, 9-24.

Dinamani, P., 1991. The Pacific oyster, Crassostrea gigas (Thunberg, 1793), in New Zealand. In: Estuarine and marine bivalve mollusk culture. Ed. by W. Wenzel. CRC Press, Boca Raton, Fla, $343-352$.

Dittmeyer, C., 1989. German market for gigas oysters. - Proceedings of the 2nd International Seminar on Pacific oysters and related species, Carlingford, County Louth, Ireland, 14-16 September, 1989, Bord Iascaigh, Dublin, $7 \mathrm{pp}$.

Eno, N. C., Clark, R. A. \& Sanderson W. G., (eds) 1997. Non-native marine species in British waters: a review and directory. - Joint Nature Conservation Committee, Peterborough, 137-138.

Grizel, H., 1988. Introduction en France de l'huitre creuse, Crassostrea gigas. - ICES, C. M. MiniSymposium on Case-histories of the effect of transfers and introductions on marine resources, 10 October 1988, Bergen, Norway 1,8 pp.

ICES, 1994. Code of Practice on the Introductions and Transfers of Marine Organisms. - Rep. Adv. Comm. Mar. Environ., Annex 3 ICES Coop. Res. Rep. 204, 95-98.

Imai, T. \& Sakai, S., 1961. Study on breeding of the Japanese oyster Crassostrea gigas. - Tohoku J. Agric. Res. 12, 125-171.

Korringa, P., 1976. Farming the cupped oyster of the genus Crassostrea. Developments in aquaculture and fisheries science, vol. 2. Elsevier, Amsterdam, $224 \mathrm{pp}$.

Menzel, R. W., 1974. Portuguese and Japanese oysters are the same species. - J. Fish. Res. Board Can., 31, 453-456.

Neudecker, T., 1985. Untersuchungen zur Reifung, Geschlechtsumwandlung und künstlichen Vermehrung der pazifischen Auster Crassostrea gigas in deutschen Gewässern. - Veröff. Inst. Küst. Binnenfisch., Hamburg, 88, $212 \mathrm{pp}$.

Quayle, D. B., 1988. Pacific oyster culture in British Columbia. - Can. Bull. Fish. Aquat. Sci. 218, $241 \mathrm{pp}$.

Reise, K., 1998. Pacific oysters invade mussel beds in the European Wadden sed. - Senckenb. Marit. 28, 167-175.

Steele, E. N., 1964. The immigrant oyster, now known as the Pacific oyster. - Warren's Quick Print, Olympia, Washington, 179 pp.

Utting, S. D. \& Spencer, B. E., 1992. Introductions of marine bivalve molluscs into the United Kingdom for commercial culture. - ICES Mar. Sci. Symp., 84-91.

Walne, P. R. \& Helm, M. M., 1979. Introduction of Crassostrea gigas into the United Kingdom. - In: Exotic species in mariculture. Ed. by R. Mann. MIT Press, Cambridge, Mass., 83-105.

Walne, P. R. \& Spencer, B. E., 1971. The introduction of the Pacific oyster Crassostrea gigas into the UK - MAFF Shellfish Information Leaflet, Fish. Lab., Burnham, 21, 14 pp.

In addition to the cited literature, the ICES Yearly Administrative Reports of the Shellfish and Mariculture Committee, monthly reports to the Directory of the Neth. Inst. Fish. Invest. by the Head of the Molluscan Shellfish and Mariculture Dept. 1955-1987, and personal communications by J. C. Bayes (Seasalter Shellfish Ltd., Whitstable, Kent) and E. Edwards (S.A.G.B., London) were used as sources. 